\title{
CAPITALIZATION OF WASTEWATER-GROWN ALGAE IN BIOETHANOL PRODUCTION
}

\author{
Nicoleta Ungureanu ${ }^{1}$, Valentin Vladut ${ }^{2}$, Sorin-Stefan Biris ${ }^{1}$ \\ ${ }^{1}$ University Politehnica of Bucharest, Romania; \\ ${ }^{2}$ National Institute of Research-Development for Machines and Installations \\ Designed to Agriculture and Food Industry, Romania \\ nicoletaung@yahoo.com, valentin_vladut@yahoo.com, biris.sorinstefan@gmail.com
}

\begin{abstract}
Global environmental policies to reduce the emissions of greenhouse gases and to increase the use of renewable energy have created premises for identification and exploitation of new, economic and non-polluting resources. Algae biomass has gained interest in the production of bioethanol because it is renewable, carbonneutral, sustainable and can be cultivated in non-productive, non-arable land (without competing with production of food crops) or in fresh and grey water. Algae can grow in wastewater (in open ponds and photobioreactors), contributing to wastewater treatment, reducing nutrients (nitrogen and phosphorous), chemical oxygen demand, biochemical oxygen demand, suspended solids, heavy metals and coliforms. Algal biomass has fast growth-rate (12 days) and the doubling time during exponential growth is only 3.5 hours. Macroalgae contains carbohydrates (starch, cellulose and hemicellulose) and undergoes pretreatments (acidic, alkaline, or enzymatic hydrolysis) to obtain reducing sugars, which are fermented with yeast to obtain bioethanol. Many strains of algae grown in wastewater, including Chlorella, Chlamydomonas, Dunaliella, Porphyridium, Spirogyra and Spirulina contain up to $50 \%$ of their dry weight carbohydrates (starch and glycogen) and are converted into bioethanol. Global production and consumption of bioethanol are expected to increase to 134.5 billion liters by 2024. This paper presents the importance of cultivating algae in wastewater, and reviews the most recent achievements in the production of third generation bioethanol from algae strains using acid, alkali and enzymatic pretreatments, respectively the importance of Saccharomyces cerevisiae for the fermentation of sugars extracted from algae.
\end{abstract}

Keywords: wastewater, microalgae, carbohydrates, saccharification, bioethanol.

\section{Introduction}

According to FAO, in 2016 the global bioethanol production was 100.2 billion litres and is expected to increase to nearly 134.5 billion litres by 2024. Shares of bioethanol production in 2024 refer to $2 \%$ Thailand, $2 \%$ India, $7 \%$ China, $7 \%$ the European Union, $31 \%$ Brazil, $42 \%$ the USA and $9 \%$ other countries. Small differences are given for bioethanol consumption: $2 \%$ Thailand, $2 \%$ India, $7 \%$ China, $8 \%$ the European Union, $29 \%$ Brazil, $41 \%$ the USA and $11 \%$ other countries [1]. It is expected that biofuels will cover $30.7 \%$ of total transport energy demand by 2060 [2].

Bioethanol feedstock includes: sugar-containing biomass (sugarcane, sugar beets, sweet sorghum, whey, molasses), starch-containing biomass (corn, wheat, whey, barley, grain sorghum, potato, cassava, Jerusalem artichoke, beverage residues) and lignocellulosic biomass (straws, corn stover, rice hulls, olive pulp, forestry residues, bagasse, switchgrass, alfalfa, respectively wood residues which contain $43 \%$ cellulose, $27 \%$ lignin, $20 \%$ hemicellulose and $10 \%$ other components.

About $40 \%$ of the global bioethanol production is mostly from sugarcane and sugar beet and $60 \%$ is from starch-containing feedstock [3]. Although the lignocellulosic biomass is much cheaper for biofuel production than sugar and starch-based feedstock, the technology leading to its conversion into ethanol is currently under development worldwide [4].

Biofuels produced from crops cultivated in arable land are in competition with the food industries, which lately is rising strong opposition in Europe and globally. In this context, new resources like algae have gained increasing interest in biofuels production. Algae are renewable, sustainable, carbonneutral, and can be cultivated in non-productive, non-arable land, reducing the threats on food security. Microalgae have fast growth rate and a very short harvesting cycle (1-10 days) compared to other biomass feedstocks, and their doubling time during exponential growth is 3.5 hours.

Algae can grow in municipal, livestock, agricultural and industrial wastewater, consuming the macronutrients $(\mathrm{C}, \mathrm{N}, \mathrm{P}, \mathrm{S})$ and micronutrients $(\mathrm{Co}, \mathrm{Cu}, \mathrm{Fe}, \mathrm{Mn}, \mathrm{Mg}, \mathrm{Mo}, \mathrm{Zn}$ ) [5] which otherwise would cause eutrophication. Growing in wastewater (in open ponds, and more recently in photobioreactors consisting of transparent plastic bags, flat and alveolar panels, Plexiglas, acrylic and glass tubes, or flexible plastic coils) [6], algae contribute to wastewater treatment without aeration by the symbiotic growth of photosynthetic algae and bacteria, reducing nutrients $(\mathrm{N}$ and $\mathrm{P}$ ), organic ions, 
chemical oxygen demand, biochemical oxygen demand, suspended solids, heavy metals, pharmaceuticals, endocrine disrupters, and other harmful chemicals. Algae also reduce the pathogenic organisms, viruses, protozoa and coliform bacteria such as Salmonella, Shigella present in municipal and livestock wastewater, improving the quality of the final effluent through natural disinfection. The effluent can be recovered for irrigation of agricultural and energy crops or for landscape purposes. However, different studies stress that the microalgae can hardly grow in undiluted wastewater due to high concentrations of ammonium and other compounds frequently present in wastewater.

Algae are feed with sun energy, water, nutrients and carbon dioxide. Algae contain proteins, large amounts of carbohydrates (starch, cellulose and hemicellulose) and lipids (Fig. 1), which can be converted into biofuels (biodiesel, bioethanol, biobutanol, biogas, biohydrogen) by biochemical and thermochemical processes, chemical reactions and direct combustion. The main operations involved in algae processing for bioethanol production are presented in Fig. 2.

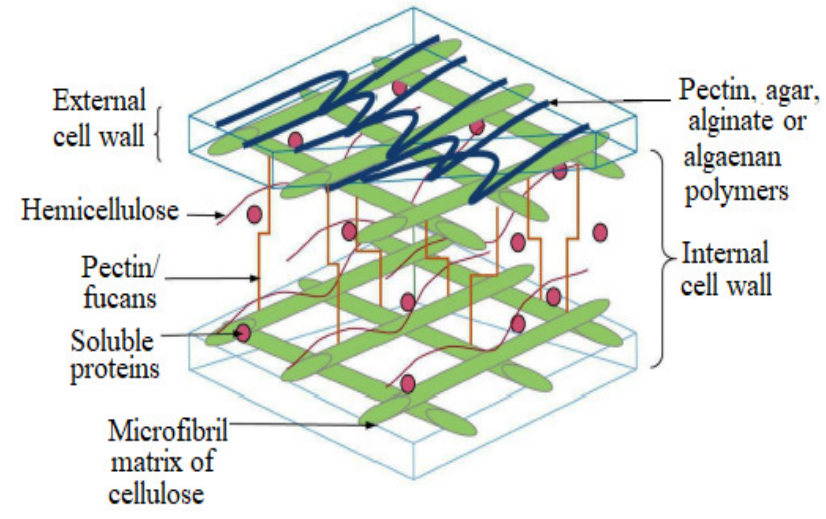

Fig. 1. Composition of microalgae cell wall [7]

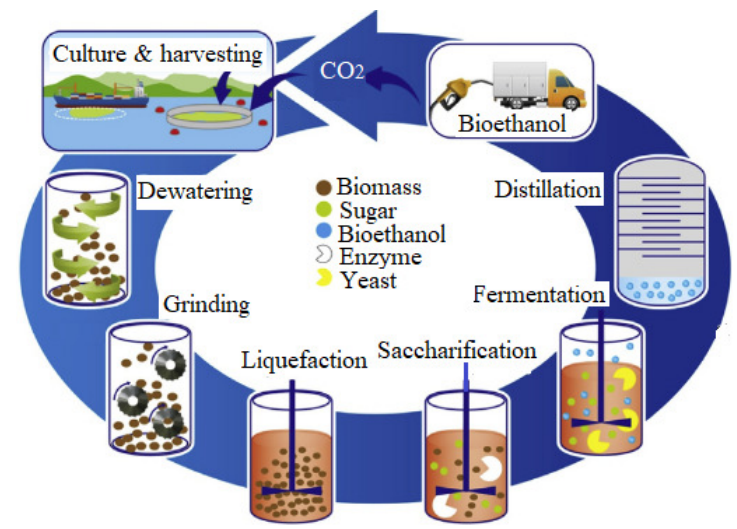

Fig. 2. Algae conversion into bioethanol [8]

Most microalgae species contain over $37 \%$ starch, which makes them useful for bioethanol production [9]. For example, wastewater-grown algae Chlorella, Chlamydomonas, Dunaliella, Porphyridium, Scenedesmus, Spirogyra, Spirulina and Tetraselmis contain $50 \%$ of their dry weight carbohydrates (starch and glycogen) which can be used for bioethanol fermentation [5]. $\mathrm{CO}_{2}$ obtained as a by-product of bioethanol fermentation can be reused to cultivate carbohydrate-rich microalgae.

Wastewater and freshwater-grown macroalgae can be a better option than microalgae in the production of bioethanol, because they have characteristics similar to plants, hence more biomass could be obtained due to their size making the harvesting process simpler, and it is possible to collect the algae residue from beaches or industry [10]. The most readily accessible carbohydrates in Laminaria, the brown seaweed macroalgae, are mannitol and laminaran (a storage glucan), which make up about $26 \%$ of its total dry mass. The starch in green seaweed could be fermented easier than the carbohydrates in brown seaweed when using standard bacteria or yeast strains, and tests are carried out on the cultivation conditions under stress to increase production [11].

Currently, the production of liquid biofuels (bioethanol, biodiesel and bio-oil) cannot be commercially implemented because liquid fuel production alone is not economically feasible. Algae capitalization for biofuel production would be economically viable if all components of microalgae biomass would be used into an integrated biorefinery to produce different products. However, microalgae-based wastewater treatment coupled with bioethanol production is a promising strategy to decrease the economic and environmental cost of biofuel production.

\section{Materials and methods}

In bioethanol production, the valuable components of microalgae biomass are the carbohydrates (starch, cellulose and hemicellulose); with little or no lignin, they are more easily hydrolyzed to monosaccharide than other lignocellulosic biomass. Starch and cellulose in microalgae are not readily fermentable to bioethanol, so pretreatments are crucial in converting them to fermentable sugars. Pretreatment processes can be physical, biological, chemical or mixed and they account for up to $30 \%$ of the total cost of algal biomass conversion [12]. 
To convert high carbohydrates contained in microalgae into bioethanol, acid, alkali or enzyme hydrolysis and subsequent fermentation with bacteria or yeast is needed [13]. The starch found in microalgae cells could be converted directly into bioethanol under dark and anaerobic conditions, although the production rate and yield of bioethanol are much lower [4].

The chemical pretreatments by acid and alkaline hydrolysis are inexpensive; they have shorter reaction time, higher capacity to hydrolyze the polymers and oligosaccharides to monosaccharides [7], with acids providing higher sugar yields than alkali [14]. Acid hydrolysis takes place in the presence of the most active cellulose hydrolysis catalyst, $\mathrm{H}_{2} \mathrm{SO}_{4}$, or $\mathrm{HCl}$ [15], in concentrations ranging from 1 to $10 \%$ at temperatures between $60-180^{\circ} \mathrm{C}$ [7] to degrade the cellulose matrix from the cell wall, depolymerize the hemicellulose and hydrolyze the starch into simple molecules to avoid the enzymatic hydrolysis [16]. Alkaline hydrolysis uses potassium hydroxide $(\mathrm{KOH})$, sodium hydroxide $(\mathrm{NaOH})$, sodium carbonate $\left(\mathrm{Na}_{2} \mathrm{CO}_{3}\right)$, or aqueous ammonia $\left(\mathrm{NH}_{4} \mathrm{OH}\right)$. The alkaline agents create pores in the cell wall to free the intracellular compounds, decreasing the size of starch polymers and the crystallinity of cellulose and starch [17]. During chemical saccharification, fermentation inhibitors (furfural and 5-hydroxymethylfurfural) are produced, but they can be neutralized by maintaining proper conditions of moisture content, temperature, residence time and concentration of the reaction agent [4].

Biological (enzymatic) hydrolysis (or saccharification) is the most promising technology and a critical step in achieving an economically viable production of bioethanol. In enzymatic saccharification, suitable and engineered enzymes such as cellulase, amylase, endo-amylase, glucanase, amyloglucosidase, xylanase or enzymatic mixtures are employed to hydrolyse the microalgae in order to obtain sugars (glucose and mannose), because each species of microalgae has different polysaccharide composition. Compared to the chemical pretreatment, the enzymatic saccharification is time consuming and relatively expensive [9], but it does not generate degradation products or toxic compounds and has higher yields of simple carbohydrates [7].

Fermentation is the process of converting the cellulosic biomass that contains sugars to bioethanol using microbes or yeasts [18], in supporting conditions of temperature and $\mathrm{pH}$. To augment the reaction, yeast-based fermentation is supplemented with nitrogen. Saccharomyces cerevisiae has been extensively used in the fermenting of sugars for bioethanol production due to its high yields (Table 1) and high tolerance to ethanol. Saccharomyces cerevisiae ferments only the hexose sugars in the hydrolyzate, but not the pentose sugars. There are only few researches on bioethanol production from microalgae with other yeasts than Saccharomyces cerevisiae.

Table 1

Biomass concentrations, sugar contents, ethanol contents and yields in some algae species after fermentation with $S$. cerevisiae [5]

\begin{tabular}{|c|c|c|c|c|}
\hline Algae species & $\begin{array}{c}\text { Biomass load, } \\
\mathbf{g} \cdot \mathbf{L}^{-1} \\
\end{array}$ & $\begin{array}{c}\text { Sugar content, } \\
\mathbf{g} \cdot \mathbf{L}^{-1} \\
\end{array}$ & $\begin{array}{c}\text { Ethanol content, } \\
\mathrm{g} \cdot \mathrm{L}^{-1} \& \mathrm{~g} \cdot \mathrm{g}^{-1} \text { biomass }\end{array}$ & $\begin{array}{c}\text { Yield, } \\
\%\end{array}$ \\
\hline Chlamydomonas rheinhardii & 50 & 28.5 & $14.6 \& 0.29$ & 100 \\
\hline Chlorococcum infusionum & 50 & - & $-\& 0.08$ & 78.4 \\
\hline Caulerpa mexicana & 38 & 22.5 & $8.5 \& 0.41$ & 72 \\
\hline Chlorella vulgaris & 10 & 1.2 & $0.6 \& 0.07$ & 89 \\
\hline Desmodesmus sp. & 100 & 55.3 & $23 \& 0.23$ & 81.4 \\
\hline Hindakia tetrachotoma & 100 & 23.5 & $11.2 \& 0.11$ & 94 \\
\hline Spirogyra sp. & 50 & 12.5 & $-\& 0.08$ & 78.4 \\
\hline Scenedesmus obliquus & 500 & 63.2 & $11.7 \& 0.023$ & 36.3 \\
\hline
\end{tabular}

Zymomonas mobilis cannot convert the pentose sugars to ethanol, so it is less used in sugar fermentation and produces less biomass than Saccharomyces [5]. Efficient yeasts that can ferment both pentose and hexose sugars include Candida shehatae, Pachysolan tannophilus and Pichia stipitis, but their yields of ethanol are five times less than those of Saccharomyces cerevisiae using glucose [18]. Kluyveromyces marxianus, Kluyveromyces fragilis, Schizosaccharomyces pombe [19] were also tested for sugars fermentation. 


\section{Results and discussion}

In extensive research carried out so far mostly at laboratory scale, various chemical and enzymatic saccharifications have been employed for the production of bioethanol from different microalgae strains. Next is presented a synthesis of the results obtained in various studies that aimed to obtain bioethanol by means of chemical and biological pretreatments of algae.

Harun et al. [20] applied the alkaline saccharification to obtain bioethanol from green algae Chlorococcum infusionum. Concentrations of $\mathrm{NaOH}$ solutions of $0.5 \%, 0.75 \%, 1 \%, 2 \%$, and $3 \%$ $(\mathrm{w} / \mathrm{v})$ with specific temperature and reaction time were tested to free the carbohydrates. The highest yield of glucose was $0.35 \mathrm{~g}$ glucose/g microalgae and highest bioethanol yield was $26.1 \%$ (g ethanol /g algae) with $0.75 \%(\mathrm{w} / \mathrm{v}) \mathrm{NaOH}$ at $120^{\circ} \mathrm{C}$ for 30 minutes. The lowest bioethanol yield was $10.66 \%$ with $1 \%(\mathrm{w} / \mathrm{v})$ of $\mathrm{NaOH}$ at $100{ }^{\circ} \mathrm{C}$ for 60 minutes. This study proved the feasibility of bioethanol production from microalgae through alkaline pretreatment. Rehman and Anal [9] have conducted a study to evaluate green algae Chlorococcum sp. TISTR 8583 for the production of bioethanol, by subjecting the algal biomass to acid, alkaline and enzyme pretreatments. Their results showed that the alkaline pretreatment was the most efficient $(23.67 \mathrm{wt} \%$ sugars per gram algal biomass: $1.2 \%(\mathrm{w} / \mathrm{v})$ at a temperature of $140{ }^{\circ} \mathrm{C}$ for 30 minutes), while the acid pretreatment $\left(1 \% \mathrm{v} / \mathrm{v}\right.$, at $\left.140{ }^{\circ} \mathrm{C}\right)$ was the least efficient with the yield of $14.83 \mathrm{wt} \%$ sugars/g algal biomass. This study proved that Chlorococcum sp. TISTR 8583 accumulates high starch and lipid contents in nutrient stress conditions.

Choi et al. [21] have tested enzymatic saccharification using two commercial hydrolytic enzymes (amylase from Bacillus licheniformis and glucoamylase from Aspergillus niger) to obtain bioethanol from Chlamydomonas reinhardtii UTEX 90 with carbohydrate content of $59.7 \%$ dry weight. When the microalgal biomass was hydrolyzed at $\mathrm{pH} 4.5$ and $55^{\circ} \mathrm{C}$ for 30 minutes, better sugar conversion of $0.57 \mathrm{~g}$ sugar per gram microalgae biomass was obtained and $235 \mathrm{mg}$ ethanol was produced from $1 \mathrm{~g}$ of microalgae by separate hydrolysis and fermentation method. The main advantages of this method include simple equipment system, low cost of chemicals, short residence time, which promote its large-scale application. In another study, Chlorococum humicola was hydrolyzed by cellulose enzymes obtained from Trichoderma reesei ATCC 26921. The enzymatic hydrolysis was carried out under varying conditions of $\mathrm{pH}$, temperature and substrate concentration, and the enzyme dosage was kept constant. The highest glucose yield of $64.2 \%$ (w/w) was obtained at $40{ }^{\circ} \mathrm{C}, \mathrm{pH} 4.8$ and a substrate concentration of $10 \mathrm{~g} \cdot \mathrm{L}^{-1}$ microalgal biomass, proving that the enzymatic hydrolysis is effective in enhancing the saccharification of microalgal biomass [22]. Kim et al. [23] used the microalgae Chlorella vulgaris in bioethanol production. Nitrogen limitation increased the total carbohydrates to $22.4 \%$ from the usual content of $16 \%$ dry weight basis. In enzymatic hydrolysis, the pentinase enzyme was superior for releasing the fermentable sugars from carbohydrates. Pectinase from Aspergillus aculeatus showed $79 \%$ saccharification yield after 3 days at $50{ }^{\circ} \mathrm{C}$. Continuous fermentation by Saccharomyces cerevisiae ( $\mathrm{pH} 5,30^{\circ} \mathrm{C}$ for 48 hours) resulted in $89 \%$ fermentation yield and $0.6 \mathrm{~g} \cdot \mathrm{L}^{-1}$ ethanol concentrations.

A study conducted by Shokrkar et al. [24] aimed to evaluate the effect of acid, alkaline, and enzymatic hydrolysis on sugar extraction from mixed microalgae. The effect of $\mathrm{MgSO}_{4}$ in acid pretreatment on reducing the sugar yield was also studied. After pretreatment, glucose in acidic and enzymatic hydrolysates of microalgae were converted into ethanol using Saccharomyces cerevisiae with yields of 0.38 and $0.46 \mathrm{~g} \cdot \mathrm{g}^{-1}$ glucose. It was found that enzymatic hydrolysis carried out during 24 hours could produce $6.01 \mathrm{~g} \cdot \mathrm{L}^{-1}$ ethanol from $13.3 \mathrm{~g} \cdot \mathrm{L}^{-1}$ sugars (glucose) derived from wet microalgal biomass, and $6.41 \mathrm{~g} \cdot \mathrm{L}^{-1}$ ethanol from $13.77 \mathrm{~g} \cdot \mathrm{L}^{-1}$ sugars were obtained from dry microalgal biomass. After 24 hours, the total ethanol yield was reduced from microalgal biomass obtained by acid hydrolysis (4.96 $\mathrm{g} \cdot \mathrm{L}^{-1}$ ethanol from $13.05 \mathrm{~g} \cdot \mathrm{L}^{-1}$ sugars derived from microalgae by acid hydrolysis: $\mathrm{H}_{2} \mathrm{SO}_{4} 0.5 \mathrm{M}$ and $2.5 \% \mathrm{MgSO}_{4}$ at $121{ }^{\circ} \mathrm{C}$ for 40 minutes). Nguyen et al. [25] tested the microalgae Chlamydomonas reinhardtii UTEX 90 as feedstock for bioethanol production. With dry cells of $5 \%$ (w/v), the microalgae was pretreated with $\mathrm{H}_{2} \mathrm{SO}_{4}(1-5 \%)$ at temperatures between 100 and $120{ }^{\circ} \mathrm{C}$, from 15 to 120 minutes. The maximum yield of glucose was $58 \%(\mathrm{w} / \mathrm{w})$ after pretreatment using $3 \%$ (v/v) $\mathrm{H}_{2} \mathrm{SO}_{4}$ at temperature of $110{ }^{\circ} \mathrm{C}$ for 30 minutes. Then, the pretreated slurry was fermented using Saccharomyces cerevisiae S288C. $14.6 \mathrm{~g} \cdot \mathrm{L}^{-1}$ bioethanol were obtained from $50 \mathrm{~g} \cdot \mathrm{L}^{-1}$ of Chlamydomonas reinhardtii UTEX 90 biomass, with $29.2 \%$ yield after the biomass was saccharified. 
To determine the maximum recovery of sugars from Scenedesmus sp., different pretreatments were applied in study [13]. The total sugar yield of $93 \%$ was obtained by acid hydrolysis. Next, the hydrolysate containing sugars $\left(15 \mathrm{~g} \cdot \mathrm{L}^{-1}\right)$ was used for ethanol fermentation using Saccharomyces cerevisiae $(5 \% \mathrm{v} / \mathrm{v})$. Most of the sugars were converted to ethanol with the yield of $6.59 \pm 0.56 \mathrm{~g} \cdot \mathrm{L}^{-1}$ after 72 hours with $180 \mathrm{rpm}$, which is equivalent to $86 \%$ theoretical yield. The mass balance of ethanol production from $1 \mathrm{~g}$ of biomass containing $0.22 \mathrm{~g}$ of carbohydrate per $\mathrm{g}$ of microalgae biomass has shown that through acid hydrolisys, the hydrolysate contains $0.2 \mathrm{~g}$ of total sugar and $0.18 \mathrm{~g}$ of fermentable sugars. Undergoing yeast fermentation, these sugars would produce $0.0791 \mathrm{~g}$ of bioethanol (86\% yield) [13]. In a similar test, the feasibility of Hindakia tetrachotoma ME03 grown in municipal wastewater with various concentrations $(0 \%, 25 \%, 50 \%, 75 \%$ and $100 \%)$ as a potential biomass feedstock to produce bioethanol in a flat-photobioreactor was studied. Acid, alkaline, and enzymatic hydrolysis were also studied for saccharification of microalgal biomass and optimized fermentation by Saccharomyces cerevisiae. After fermentation of Saccharomyces cerevisiae at 36 hours in $50 \%$ wastewater, Hindakia tetrachotoma ME03 had the maximum bioethanol content of $11.2 \pm 0.3 \mathrm{~g} \cdot \mathrm{L}^{-1}$ and yield of $94 \pm 2.2 \%$. Enzymatic hydrolysis with $\beta$-glucosidase/cellulose $+\alpha-$ amylase showed the highest saccharification $(92.3 \pm 0.9 \%)$ [5].

\section{Conclusions}

1. Studies support microalgae-based wastewater treatment coupled with bioethanol production as a promising strategy to decrease the economic and environmental cost of third generation biofuels, including bioethanol, which has been recognized as a clean and sustainable fuel.

2. Microalgae carbohydrate contents are mainly starch and cellulose, and must be hydrolysed by various pretreatment methods: chemical (acid or alkali), biological (enzymes), to fermentable sugars via microbial fermentation enhanced by Saccharomyces cerevisiae or other yeasts.

3. Despite the many advantages of algae capitalization, researches on their use as feedstock for bioethanol production are still on-going to bring bioethanol generated from micro and macroalgae to be competitive to other fossil fuel reserves.

4. Future research will be aimed at finding new possibilities to expand the current capacity of algae cultivation in domestic wastewater and wastewater from livestock farms (thus obtaining a more efficient treatment to allow the recovery of effluent in irrigation of energetic and agricultural crops), as well as in the identification and continuous improvement of technologies for harvesting algal biomass at low cost, and improved methods for the extraction of fermentable carbohydrates contained in algae, all of which ultimately have an important role in minimizing the impact on the environment.

\section{Acknowledgements}

This work was supported by a grant of the Romanian Ministry of Research and Innovation CCDI - UEFISCDI, Project INNOVATIVE TECHNOLOGIES FOR IRRIGATION OF AGRICULTURAL CROPS IN ARID, SEMIARID AND SUBHUMID-DRY CLIMATE, project number PN-III-P1-1.2PCCDI-2017-0254, Contract No. 27 PCCDI/2018, within PNCDI III.

\section{References}

[1] Food and Agriculture Organization of the United Nations. OECD-FAO Agricultural Outlook 2015. Paris, France: OECD Publishing, 2015.

[2] Alfonsín V., Maceiras R., Gutiérrez C. Bioethanol production from industrial algae waste. Waste Management, vol. 87, 2019, pp. 791-797.

[3] Bušić A., Marđetko N., Kundas S., Morzak G., Belskaya H., Ivančić Šantek M., Komes D., Novak S., Šantek B. Bioethanol production from renewable raw materials and its separation and purification: a review. Food Technology and Biotechnology, vol. 56 (3), 2018, pp. 289-311.

[4] Chen C.-Y., Zhao X.-Q., Yen H.-W., Ho S.-H., Cheng C.L., Lee D.-J., Bai F.-W., Chang J.-S. Microalgae-based carbohydrates for biofuel production. Biochemical Engineering Journal, vol. 78, 2013, pp. 1-10. 
[5] Onay M. Bioethanol production via different saccharification strategies from $H$. tetrachotoma ME03 grown at various concentrations of municipal wastewater in a flat-photobioreactor. Fuel, vol. 239, 2019, pp. 1315-1323.

[6] Ungureanu N., Vlăduț V., Biriș S.Șt., Zăbavă B.Șt., Popa M. Microalgal systems for wastewater treatment - review. Proceedings of $6^{\text {th }}$ International Conference „Research People and Actual Tasks on Multidisciplinary Sciences”, Lozenec, Bulgaria, 2019, pp. 212-217.

[7] Velazquez-Lucio J., Rodríguez-Jasso R., Colla L.M., Sáenz-Galindo A., Cervantes-Cisneros D.E., Aguilar C.N., Fernandes B.D., Ruiz H.A. Microalgal biomass pretreatment for bioethanol production: a review. Biofuel Research Journal, vol. 17, 2018, pp. 780-791.

[8] Lee O.K., Lee E.Y. Sustainable production of bioethanol from renewable brown algae biomass. Biomass and Bioenergy, vol. 92, 2016, pp. 70-75.

[9] Rehman A.U., Anal A.K. Enhanced lipid and starch productivity of microalga (Chlorococcum sp. TISTR 8583) with nitrogen limitation following effective pretreatments for biofuel production. Biotechnology Reports, vol. 21, 2019, e00298.

[10] Sudhakar K., Mamat R., Samykano M., Azmi W.H., Ishak W.F.W., Yusaf T. An overview of marine macroalgae as bioresource. Renew. Sust. Energy Rev., vol. 91, 2018, pp. 165-179.

[11]Roesijadi G., Jones S.B., Snowden-Swan L.J., Zhu I. Macroalgae as a biomass feedstock: a preliminary analysis. U.S. Department of Energy, Pacific Northwest National Laboratory PNNL19944, 2010.

[12] Talebnia F, Karakashev D, Angelidaki I. Production of bioethanol from wheat straw: an overview on pretreatment, hydrolysis and fermentation. Bioresource Technology, vol. 101 (13), 2010, pp. 4744-4753.

[13] Sivaramakrishnan R., Incharoensakdi A. Utilization of microalgae feedstock for concomitant production of bioethanol and biodiesel. Fuel, vol. 217, 2018, pp. 458-466.

[14] Harun R., Danquah M.K. Influence of acid pretreatment on microalgal biomass for bioethanol production. Process Biochem, vol. 46, 2011, pp. 304-309.

[15]Lee O.K., Seong D.H., Lee C.G., Lee E.Y. Sustainable production of liquid biofuels from renewable microalgae biomass. Journal of Industrial and Engineering Chemistry, vol. 29, 2015, pp. 24-31.

[16] Miranda J.R., Passarinho P.C., Gouveia L. Pretreatment optimization of Scenedesmus obliquus microalga for bioethanol production. Bioresource Technology, vol. 104, 2012, pp. 342-348.

[17] Harun R., Yip J.W., Thiruvenkadam S., Ghani W.A., Cherrington T., Danquah M.K. Algal biomass conversion to bioethanol-a step-by-step assessment. Biotechnology Journal, vol. 9 (1), 2014, pp. 73-86.

[18] Toor M., Kumar S.S., Malyan S.K., Bishnoi N.R., Mathimani T., Rajendran K., Pugazhendhi A. An overview on bioethanol production from lignocellulosic feedstocks. Chemosphere, vol. 242, 2020, 125080.

[19]Phwan C.K., Ong H.C., Chen W.-H., Ling T.C., Ng E.P., Show P.L. Overview: Comparison of pretreatment technologies and fermentation processes of bioethanol from microalgae. Energy Conversion and Management, vol. 173, 2018, pp. 81-94.

[20] Harun R., Jason W.S.Y., Cherrington T., Danquah M.K. Exploring alkaline pretreatment of microalgal biomass for bioethanol production. Applied Energy, vol. 88, 2011, pp. 3464-3467.

[21]Choi S.P., Nguyen M.T., Sim S.J. Enzymatic pretreatment of Chlamydomonas reinhardtii biomass for ethanol production. Bioresource Technology, vol. 101 (14), 2010, pp. 5330-5336.

[22] Harun R., Danquah M.K. Enzymatic hydrolysis of microalgal biomass for bioethanol production. Chemical Engineering Journal, vol. 168, 2011, pp. 1079-1084.

[23] Kim K.H., Choi I.S., Kim H.M., Wi S.G., Bae H.J. Bioethanol production from the nutrient stressinduced microalga Chlorella vulgaris by enzymatic hydrolysis and immobilized yeast fermentation. Bioresource Technology, vol. 153, 2014, pp. 47-54.

[24] Shokrkar H., Ebrahimi S., Zamani M. Bioethanol production from acidic and enzymatic hydrolysates of mixed microalgae culture. Fuel, vol. 200, 2017, pp. 380-386.

[25] Nguyen M.T., Choi S.P., Lee J., Lee J.H., Sim S.J. Hydrothermal acid pretreatment of Chlamydomonas reinhardtii biomass for ethanol production. Journal of Microbiology and Biotechnology, vol. 19, 2009, pp. 161-166. 